\title{
THE ANNUAL MEETING IN ST. LOUIS
}

The forty-second Annual Meeting of the American Mathematical Society was held in St. Louis, Missouri, from Tuesday to Thursday, December 31, 1935-January 2, 1936. Washington University and St. Louis University acted as hosts. All sessions of the Society except the Gibbs Lecture were held in the Commerce and Finance Building of St. Louis University. The Gibbs Lecture was held in the Municipal Auditorium.

The scientific meetings were opened on Tuesday morning in two sections, one for Analysis and one for Number Theory and Algebra. On Tuesday afternoon there was a joint session of the American Mathematical Society, the Mathematical Association of America, and Section A of the American Association for the Advancement of Science. At this session Professor R. D. Carmichael delivered his retiring address as Vice-President of the American Association for the Advancement of Science and Chairman of Section A. His subject was Linear differential equations of infinite order. By invitation of the Committee on Program, Professor J. L. Synge gave a lecture entitled Tensorial methods in dynamics. Professors T. H. Hildebrandt and Solomon Lefschetz presided in turn at this session.

There were general sessions on Wednesday morning and afternoon. On Wednesday afternoon Professor Gabriel Szegö, by invitation of the Committee on Program, addressed the Society on Some recent investigations concerning sections of trigonometric and related series. Professor Lefschetz presided.

At a joint session on Statistics with the Econometric Society and the Institute of Mathematical Statistics on Thursday morning, Professor Thomas Rawles gave an address entitled Mathematical theory of index numbers. Professor H. L. Rietz presided. There was also a section on Analysis at this time.

The Society met on Thursday afternoon in two sections, one for Analysis and Applied Mathematics and one for Geometry. Later in the afternoon at a meeting of the Society which was also a general session of the American Association for the Advancement of Science, Professor Vannevar Bush of the Massachusetts Institute of Technology delivered the twelfth Josiah 
Willard Gibbs Lecture, entitled Mechanical analysis. Professor K. T. Compton, President of the American Association for the Advancement of Science, presided.

On Tuesday afternoon members of this Society and the Mathematical Association were guests of the Washington University chapter of Pi Mu Epsilon on a short sightseeing trip followed by a tea in the Women's Building of Washington University.

The banquet of the members of the Society and the Mathematical Association and their guests was held on Wednesday evening in the Coronado Hotel. Two hundred twenty-six persons attended this dinner. Professor R. D. Carmichael acted as toastmaster. He called on Professors W. H. Roever, W. C. Graustein, and E. R. Hedrick. The dinner was adjourned in time for members to attend a lecture by Professor R. C. Archibald on Babylonian mathematics with special reference to recent discoveries, which was given in connection with the dinner of the National Council of Teachers of Mathematics. A resolution of thanks was passed to the many people in St. Louis whose work had contributed to the success of the meeting.

The Board of Trustees held a meeting in the Coronado Hotel on December 31, 1935, and an adjourned meeting in the Faculty Club of Columbia University at 4:45 p.m. on January 4, 1936. The Council met in the Coronado Hotel at 7:30 p.m. on December 31, 1935. The Annual Business Meeting was held on Wednesday afternoon at 2:00 p.m. Two hundred eighteen ballots were cast and the following officers were elected:

Vice-Presidents, Professors E. B.Stouffer and Norbert Weiner. Secretary, Dean R. G. D. Richardson.

Treasurer, Professor G. W. Mullins.

Associate Secretaries, Professors M. H. Ingraham and T. M. Putnam.

Librarian, Professor R. C. Archibald.

Member of the Editorial Committee of the Bulletin, Professor D. R. Curtiss.

Member of the Editorial Committee of the Transactions, Professor W. C. Graustein.

Member of the Editorial Board of the American Journal of Mathematics, Professor J. F. Ritt.

Member of the Editorial Committee of the Colloquium Publications, Professor Oswald Veblen. 
Members of the Council, Professors Jesse Douglas, M. H. Stone, J. M. Thomas, T. Y. Thomas, R. M. Winger.

It was announced that the following eighty-seven persons had been elected to membership in the Society:

Mr. Lovincy Joseph Adams, Beverly Hills High School, Beverly Hills, California;

Mr. George Eugene Albert, University of Wisconsin;

Professor Hugh H. Barr, Harris Teachers College, St. Louis, Missouri;

Dr. Gertrude Blanch, Hunter College;

Miss Jessie W. Boyce, State Teachers College, Wayne, Nebraska;

Mr. Samuel Bronstein, Hartford Federal College, Hartford, Connecticut;

Dr. Newton Henry Brown, Arkansas State College, Jonesboro, Arkansas;

Miss Adelaide W. Bull, Essex County Junior College, Newark, New Jersey;

Professor Ezra John Camp, Yankton College;

Professor Loula Martha Caraher, Arkansas State Teachers College, Conway, Arkansas;

Professor William H. H. Cowles, Pratt Institute;

Professor Harry E. Crull, University of Southern California;

Professor Walter Thomas Daniels, Negro Agricultural and Technical College, Greensboro, North Carolina;

Professor Robert Dodds Daugherty, Kansas State College;

Mr. Uri P. Davis, University of Florida;

Dr. Thomas Luther Downs, Harvard University;

Professor Lyle Walker Finley, Monmouth College, Monmouth, Illinois;

Professor Bernice Colette Fites, Nazareth College, Nazareth, Michigan;

Mr. Irving Gordon Foster, University of Wisconsin;

Dr. Donald L. Fuller, American Cyanamid Company, Linden, New Jersey;

Brother Godfrey Vassallo, University of Portland, Portland, Oregon;

Mr. Julius Goldman, Detroit Institute of Technology;

Mr. Willard Lee Graves, University of Pennsylvania;

Miss Harriet M. Griffin, Brooklyn College;

Dr. Borghild Gunstad, University of Minnesota;

Mrs. Euphemia L. Haynes, Miner Teachers College, Washington, D. C.;

Professor Eugene W. Hellmich, Northern Illinois State Teachers College, DeKalb, Illinois;

Mrs. Susanne Edmondson Hotelling, New York City;

Mr. Joseph Jablonower, Fieldston School, New York City;

Mr. Robert Franklin Jackson, Harvard University;

Dean Paul Vernon Jewell, State Agricultural and Mechanical College, Orangeburg, South Carolina;

Dr. Nathan Kaplan, Brockton, Massachusetts;

Mr. Albert Arthur Koch, United States Engineers Office, Los Angeles;

Mr. Frank A. La Motte, Junior College, Centenary Collegiate Institute, Hackettstown, New Jersey;

Mrs. Lillian R. Lieber, Long Island University;

Professor Maceo Windfield Long, Samuel Huston College, Austin, Texas; 
Dr. Arnold Noah Lowan, Yeshiva College, New York City;

Mr. Charles Anthony McCane, Miner Teachers College, Washington, D. C.;

Professor Willis Franklin Maclin, Mississippi Industrial College, Holly Springs, Mississippi;

Professor Frank P. Maguire, State Teachers College, East Stroudsburg, Pennsylvania;

Sister Maria Corona, College of Mount St. Joseph, Mount St. Joseph, Ohio;

Sister Mary Angela Margraf, Ursuline College, Cleveland, Ohio;

Sister Mary Resignata, Clarke College, Dubuque, Iowa;

Professor Julio A. Mira, College of the Sacred Heart, New York City;

Professor Sara Louise Nelson, Georgia State College for Women, Milledgeville, Georgia;

Mr. Edward Alfred Nordhaus, University of Wisconsin, Extension Center;

Mr. Hubert V. Park, State College of Agriculture and Engineering of the University of North Carolina;

Mr. Donald Theodore Perkins, Yale University;

Professor Charles Semple Pettis, Wofford College, Spartansburg, South Carolina;

Miss Theresa Louise Podmele, East High School, Buffalo, New York;

Professor J. W. Querry, Sam Houston State Teachers College, Huntsville, Texas;

Mr. K. Nagaraja Rao, Annamalai University, Annamalainagar, South India;

Dr. Louis M. Rauch, Berkeley, California;

Professor Bruce Hampton Redditt, Northeast Center, Louisiana State University, Monroe, Louisiana;

Professor Fred R. Reel, Lewis Institute, Chicago, Illinois;

Dr. Malcolm Slingsby Robertson, Yale University;

Dr. Willis Brainard Robinson, American International College;

Mr. Walter Roth, State University of Iowa;

Mr. John T. Rule, Taylor School for Boys, Clayton, Missouri;

Dean Henry Thomas Sampson, Jackson College, Jackson, Mississippi;

Mr. Max Sasuly, National Recovery Administration, Department of Commerce, Washington, D. C.;

Professor John Schon, St. Joseph's College, Collegeville, Indiana;

Professor Laurence W. Sheridan, St. Thomas College, Scranton, Pennsylvania;

Professor Victor Louis Sherman, Lewis Institute, Chicago, Illinois;

Professor Edwin Roscoe Sleight, Albion College, Albion, Michigan;

Mr. Charles Bassel Smith, University of Wisconsin;

Mr. Robert Edward Smith, Meadville, Pennsylvania;

Rev. Frederick Wyatt Sohon, Georgetown University;

Mr. Oswald S. Specht, Union College, Lincoln, Nebraska;

Professor Frederick H. Steen, Georgia School of Technology;

Professor Wren A. Stone, New Mexico Agricultural and Mechanical College, State College, New Mexico;

Professor Joseph Manual Synnerdahl, St. Francis Xavier College for Women, Chicago, Illinois:

Professor Walter Richard Talbot, Lincoln University, Jefferson City, Missouri; 
Dean Marion B. Tolar, Fenn College, Cleveland, Ohio:

Professor Joseph C. Trainor, Washington State Normal School, Ellenburg, Washington;

Mr. Waldo Anthony Vezeau,.St. Louis University;

Mr. John Ord Watts, Queen's University;

Professor Edward B. Wedel, Holdenville Junior College, Holdenville, Oklahoma;

Mr. Robert Lewis Westhafer, Hastings College, Hastings, Nebraska;

Professor Leslie Harper Whitcraft, Ball State Teachers College, Muncie, Indiana;

Miss Angeline Wilson, Grand Rapids Junior College, Grand Rapids, Michigan;

Professor William Woodhull Wood, Davidson College;

Mr. John William Wrench, Jr., Yale University;

Mr. John Franklin Wyckoff, South Dakota State College;

Dr. Clarence R. Wylie, Ohio State University;

Mr. Herbert Zuckerman, University of California.

As nominee of Brooklyn College: Mr. Vincent Dillon, Brooklyn College.

The secretary reported that the following persons had been admitted to membership in the Society in accordance with the reciprocity agreement with the London Mathematical Society:

Professor Edward Thomas Copson, University College, Dundee, Scotland;

Professor B. R. Seth, Hindu College, Delhi, India;

Professor S. M. Shah, Muslim University, Udebir Compound, Aligarh, India.

The following ten institutions and groups were elected to institutional membership in the Society:

Bowdoin College;

Department of Mathematics of Brooklyn College;

Connecticut College;

Dartmouth College;

Department of Mathematics of the University of Illinois;

University of Kansas;

Louisiana State University;

Pennsylvania State College;

Stevens Institute of Technology;

University of Virginia.

The Secretary reported that the membership in the Society is now 1863, including 117 contributing members, 75 nominees of institutional members and 79 life members. There are also 77 institutional members. The total attendance of members at all meetings in 1935 was 959 ; the number of papers read was 436 ; the number of members attending at least one meeting was 618 .

The reports of the Treasurer and of the auditors (Professor 
B. P. Gill and Mr. S. A. Joffe) showed a balance of $\$ 9,837.14$ exclusive of the balances of the Bulletin, Transactions, Colloquium, Journal, Library, Sinking Fund, and special funds. The Society's Endowment Fund is invested in securities valued at $\$ 72,568.26$ (as amortized in March, 1934). The income from various sources as listed in the Treasurer's report was:

Annual dues and initiation fees
Sale of publications
Contributions toward publication
Institutional memberships
Individual contributing memberships
Rockefeller subvention
Special contributions
Interest from endowment
Other interest and miscellaneous

Total income for 1935

$$
\begin{array}{r}
\$ 12,069.02 \\
11,620.24 \\
644.88 \\
5,605.00 \\
907.00 \\
4,500.00 \\
198.50 \\
2,863.03 \\
997.71 \\
\hline \$ 39,405.38
\end{array}
$$

The receipts from sales of the Society's publications does not include receipts from Bliss's Algebraic Functions, which have been transmitted to the Revolving Book Fund of the National Research Council, or income of special funds. The Trustees adopted a budget for 1936 showing estimated expenditures and receipts as $\$ 34,211.35$ and $\$ 31,550.00$, respectively. The indicated deficit, however, is largely fictitious as it is represented by outstanding bills which will be paid from the 1935 balances.

The Librarian reported that the Library of the Society now contains 8,612 volumes.

The following appointments were reported: as acting-treasurer until October 1, 1936, Professor P. A. Smith; as tellers for the election at the annual meeting, Professor Otto Dunkel and Dr. E. R. Lorch; as representative on the National Research Council for the period beginning July 1, 1936, to succeed Dean R. G. D. Richardson, Dr. T. C. Fry; as representatives on the Council of the American Association for the Advancement of Science for 1936, Professors M. H. Ingraham and C. N. Moore; as committee on arrangements for the 1936 annual meeting in Washington, D. C., Professors J. H. Taylor (chairman), F. E. Johnston, J. R. Kline, A. E. Landry, F. M. Weida, and $\mathrm{Mr}$. W. D. Lambert; as the nominating committee, Pro- 
fessors A. B. Coble (chairman), Marston Morse, M. H. Stone, E. B. Stouffer, and R. L. Wilder; as representative of the Society at the inauguration of Alan Valentine as president of the University of Rochester, November 15, 1935, Professor Virgil Snyder; as representative of the Society at the inauguration of John Ahlum Schaeffer as president of Franklin and Marshall College, December 6, 1935, Professor J. R. Kline; as additional members of the committee on arrangements for the 1935 annual meeting, Dr. Francis Regan and Dean A. S. Langsdorf; as representative of the Society at the inauguration of C. Valentine Boyer as president of the University of Oregon, February 6, 1936, Professor F. L. Griffin.

It was reported that Professor Jesse Douglas had accepted the invitation to give the Colloquium Lectures in 1937 and that his subject would be The problem of Plateau.

It was announced that the first volume of E. H. Moore's General Analysis has been published by the American Philosophical Society and that the University of Pennsylvania Press is acting as agent in its distribution.

Future meetings of the Society were announced as follows: Seattle, June 18; New York, October 31; Lawrence, Kansas, November 27-28.

The editors of the Transactions announced that the following persons had been asked to act as associate editors for 1936: Professors A. A. Albert, E. T. Bell, Jesse Douglas, T. H. Hildebrandt, Einar Hille, E. P. Lane, R. E. Langer, C. C. MacDuffee, Marston Morse, G. Y. Rainich, H. L. Rietz, M. H. Stone, J. L. Synge, G. T. Whyburn, and Oscar Zariski, and Dr. Caroline E. Seely (until July).

About three hundred persons attended the sessions other than the Gibbs Lecture. This attendance included the following two hundred thirty members:

V. W. Adkisson, E. S. Allen, C. B. Allendoerfer, N. B. Allison, N. L. Anderson, W. E. Anderson, R. C. Archibald, C. S. Atchison, H. T. Aude, R. W. Babcock, Wealthy Babcock, C. L. Bacon, H. W. Bailey, G. A. Baker, R. W. Barnard, I. A. Barnett, H. H. Barr, W. D. Baten, A. A. Bennett, Hermann Betz, William Betz, Solomon Bilinsky, F. L. Black, Archie Blake, Henry Blumberg, L. M. Blumenthal, Salomon Bochner, D. G. Bourgin, O. K. Bower, J. W. Boyce, J. W. Bradshaw, W. C. Brenke, R. W. Brink, F. L. Brooks, G. S. Bruton, R. S. Burington, J. Hughes Bushey, W. D. Cairns, B. H. Camp, C. C. Camp, R. D. Carmichael, H. C. Carter, E. W. Chittenden, A. B. Coble, 
L. M. Coffin, L. W. Cohen, J. B. Coleman, J. T. Colpitts, E. G. H. Comfort, J. J. Corliss, Byron Cosby, N. A. Court, A. T. Craig, C. C. Craig, Paul Cramer, A. R. Crathorne, D. R. Curtiss, J. H. Curtiss, E. H. Cutler, R. D. Daugherty, H. T. Davis, Vincent Dillon, L. L. Dines, J. L. Doob, Otto Dunkel, P. D. Edwards, H. J. Ettlinger, H. S. Everett, G. M. Ewing, B. F. Finkel, C. H. Fischer, T. C. Fry, F. J. Gerst, J. L. Gibson, W. C. Graustein, F. L. Griffin, Marshall Hall, E. H. Hanson, E. G. Harrell, E. L. Harris, W. L. Hart, W. W. Hart, M. C. Hartley, M. L. Hartung, J. O. Hassler, T. W. Hatcher, E. R. Hedrick, C. B. Hennel, Fritz Herzog, D. M. Hickey, T. H. Hildebrandt, J. J. L. Hinrichsen, P. G. Hoel, M. A. Holly, H. M. Hosford, E. M. Hove, Mildred Hunt, W. A. Hurwitz, C. A. Hutchinson, Emma Hyde, M. H. Ingraham, Joseph Jablonower, Dunham Jackson, Nathan Jacobson, R. D. James, R. L. Jeffery, M. M. Johnson, L. C. Karpinski, D. E. Kearney, Claribel Kendall, G. S. Ketchum, P. W. Ketchum, E. W. King, S. C. Kleene, E. E. Knight, J. C. Knipp, Alfred Korzybski, J. H. Kusner, Cornelius Lanczos, C. G. Latimer, Solomon Lefschetz, Harry Levy, M. I. Logsdon, Dorothy McCoy, J. V. McKelvey, A. S. McMaster, C. C. MacDuffee, Saunders MacLane, V. S. Mallory, Morris Marden, Anna Marm, W. T. Martin, Mary N. Arnoldy, J. R. Mayor, C. W. Mendel, H. A. Meyer, H. J. Miles, W. E. Milne, W. L. Miser, U. G. Mitchell, E. C. Molina, Deane Montgomery, C. N. Moore E. J. Moulton, S. B. Myers, M. M. Ness, C. V. Newsom, G. D. Nichols, C. O. Oakley, Alta Odoms, Rufus Oldenburger, E. G. Olds, Arthur Ollivier, J. O. Osborn, W. V. Parker, W. O. Pennell, O. J. Peterson, H. B. Phillips, A. E. Pitcher, H. S. Pollard, J. W. Querry, T. C. Rafferty, J. F. Randolph, T. H. Rawles, Francis Regan, B. L. Remick, D. P. Richardson, R. G. D. Richardson, H. L. Rietz, R. F. Rinehart, W. C. Risselman, J. H. Roberts, Robin Robinson, S. L. Robinson, W. H. Roever, Rose M. Cook, A. E. Ross, M. F. Rosskopf, W. E. Roth, J. T. Rule, L. L. Runge, R. G. Sanger, M. G. Scherberg, I. J. Schoenberg, L. S. Shively, R. L. Short, C. H. Sisam, C. D. Smith, E. R. Smith, G. W. Smith, H. L. Smith, R. G. Smith, F. W. Sohon, I. S. Sokolnikoff, A. A. Stafford, G. W. Starcher, J. Y. Stephens, Guy Stevenson, R. W. Stokes, E. B. Stouffer, W. T. Stratton, J. L. Synge, Gabriel Szegö, J. D. Tamarkin, M. E. Taylor, E. L. Thorndike, E. W. Titt, W. J. Trjitzinsky, C. B. Tucker, H. W. Tyler, A. L. Underhill, J. H. Van Vleck, J. I. Vass, W. A. Vezeau, G. E. Wahlin, R. J. Walker, L. E. Ward, W. G. Warnock, J. H. Weaver, Warren Weaver, M. J. Weiss, W. D. A. Westfall, J. J. Wheeler, L. H. Whitcraft, H. S. White, W. M. Whyburn, K. P. Williams, F. L. Wren, Kathryn Wyant, M. M. Young.

Titles and cross references to abstracts of papers read at the regular sessions follow below. Mr. Sewell was introduced by Professor Walsh, Dr. Norris by Professor C. C. Craig, Dr. Downs by Professor Graustein, Mr. Larguier by Professor Regan, and Mr. Zuckerman by Dr. James. The joint paper by Professor Barnett and Dr. Mendel was read by Professor Barnett; that of Professor Morse and Mr. Pitcher, by Mr. Pitcher; that of Professor Montgomery and Dr. Zippin, by Pro- 
fessor Montgomery. The paper by Dr. Hamilton was read by Professor Ettlinger.

The papers were read as follows: papers numbered 1 to 9 in the Section on Analysis Tuesday morning, Professor H. B. Phillips presiding; papers numbered 10 to 16 in the Section on Number Theory and Algebra Tuesday morning, Professor C. C. MacDuffee presiding; papers numbered 17 to 25 in the General Session on Wednesday morning, Professors Solomon Lefschetz and W. A. Hurwitz presiding; papers numbered 26 to 29 in the General Session on Wednesday afternoon, Professor E. B. Stouffer presiding; papers numbered 30 to 33 in the section for Statistics on Thursday morning, Professor H. L. Rietz presiding; papers numbered 34 to 40 in the Section for Analysis on Thursday morning, Professors Solomon Lefschetz and Henry Blumberg presiding; papers numbered 41 to 45 in the section for Analysis and Applied Mathematics on Thursday afternoon, Professor C. N. Moore presiding; papers numbered 46 to 57 in the section for Geometry on Thursday afternoon, Professor Solomon Lefschetz presiding. The papers whose abstract numbers are followed by the letter $t$ were read by title.

1. On a certain integral equation quadratic in the unknown function, by Professor I. A. Barnett and Dr. C. W. Mendel. (Abstract No. 42-1-14.)

2. A note on the degree of polynomial approximation, by Dr. J. H. Curtiss. (Abstract No. 42-1-29.)

3. Theory of linear differential equations containing a parameter, by Professor W. J. Trjitzinsky. (Abstract No. 41-11-404.)

4. On a problem of approximation associated with a periodic Stieltjes fraction, by Professor W. C. Risselman. (Abstract No. 42-1-36.)

5. Location of the level curves of Green's function, by Mr. W. E. Sewell. (Abstract No. 42-1-11.)

6. Invariants of closed extremals, by Professor Marston Morse and Dr. A. E. Pitcher. (Abstract No. 42-1-69.)

7. On the momentum problem for distribution functions in more than one dimension, by Dr. E. K. Haviland. (Abstract No. 42-161-t.)

8. A generalization of Markoff's theorem, by Mr. W. E. Sewell. (Abstract No. 42-1-68-t.) 
9. Indeterminate expressions involving an arbitrary function and its derivatives, by Professor J. F. Ritt. (Abstract No. 42-1-70-t.)

10. Characteristic roots of direct products of n-way matrices, by Dr. Rufus Oldenburger. (Abstract No. 42-1-52.)

11. A note on null sequences, by Mr. Marshall Hall. (Abstract No. 42-1-12.)

12. On the class number of a quaternion algebra with a negative fundamental number, by Professor C. G. Latimer. (Abstract No. 41-11-386.)

13. The number of representations of an integer as a sum of twelve, sixteen, or twenty squares, by Dr. R. D. James. (Abstract No. 42-1-22.)

14. A construction of prime ideals in terms of absolute values of an algebraic field, by Dr. Saunders MacLane. (Abstract No. 41-11-384.)

15. On the matrices $A B$ and $B A$, by Professor W. E. Roth. (Abstract No. 42-1-73.)

16. On the Hilbert-Netto theorem for algebraic differential equations, by Professor H. W. Raudenbush, Jr. (Abstract No. 421-66-t.)

17. The metric characterization of a certain class of spaces, by Dr. L. M. Blumenthal. (Abstract No. 42-1-47.)

18. Dual abelian groups, by Dr. Leo Zippin. (Abstract No. 42-1-38-t.)

19. Many-parameter groups in n-space, by Professor Deane Montgomery and Dr. Leo Zippin. (Abstract No. 42-1-33.)

20. On the groups associated with certain cyclic curves (preliminary report), by Professor V. W. Adkisson. (Abstract No. 42-1-24.)

21. Orthogonal polynomials in two variables: formal properties, by Professor Dunham Jackson. (Abstract No. 42-1-18.)

22. The equivalence of sequence integrals and non-absolutely convergent integrals, by Professor R. L. Jeffery. (Abstract No. 42-1-54.)

23. On restricted convergence and restricted summability of double series, by Professor C. N. Moore. (Abstract No. 42-1-34.)

24. A note on recursive functions, by Dr. S. C. Kleene. (Abstract No. 42-1-74.)

25. A Grace-Heawood theorem for the critical points of Green's function, by Professor Morris Marden. (Abstract No. 42-1-72.) 
26. On semi-linear equations, by Professor C. O. Oakley. (Abstract No. 42-1-27.)

27. Critical sets for functions, by Professor W. M. Whyburn. (Abstract No. 42-1-41.)

28. Complex rational fractions, by Professor L. R. Ford. (Abstract No. 42-1-49-t.)

29. A new approximation method in solving linear differential equations with rational coefficients, by Professor Cornelius Lanczos. (Abstract No. 42-1-32.)

30. On certain distributions derived from the multinomial distribution, by Dr. Solomon Kullback. (Abstract No. 41-11-385-t.)

31. Convexity properties of generalized mean value functions, by Dr. Nilan Norris. (Abstract No. 42-1-13.)

32. The frequency distribution for the mean of $n$ independent chance variables when each is subject to the law $y_{0} x^{p-1}(1-x)^{q-1}$, by Professor W. D. Baten. (Abstract No. 42-1-56.)

33. On the admissibility of time series, by Professor Francis Regan. (Abstract No. 42-1-6.)

34. Cauchy's problem for the non-linear hyperbolic differential equation in three independent variables, by Dr. E. W. Titt. (Abstract No. 42-1-40.)

35. Carathéodory linear measure and Vitali's theorem, by Dr. J. F. Randolph. (Abstract No. 42-1-45.)

36. On the symmetrical structure of general point sets, by Professor Henry Blumberg. (Abstract No. 42-1-46.)

37. Cauchy fields of ordinary differential equations, by Professor H. J. Ettlinger. (Abstract No. 42-1-25.)

38. Non-unique solutions of first order ordinary differential equations, by Mr. O. H. Hamilton. (Abstract No. 42-1-26.)

39. Summation of general Fourier expansions on closed Lie groups, by Professor Salomon Bochner. (Abstract No. 42-1-75.)

40. Extensionalization in mathematics, mathematical physics, and general education: general semantics, by Count Alfred Korzybski. (Abstract No. 42-1-64.)

41. On the zeros of successive derivatives of integral functions, by Professor I. J. Schoenberg. (Abstract No. 42-1-37.)

42. On the logarithmic mean of double Fourier series, by Miss Alta Odoms. (Abstract No. 42-1-35.)

43. Temperature distribution in a slab of two layers, by Professor R. V. Churchill. (Abstract No. 42-1-16-t.) 
44. The problem of the sheet, by Dr. D. G. Bourgin. (Abstract No. 42-1-43.)

45. The dynamical theory of electrical commutator machinery (preliminary report), by Professor J. L. Synge. (Abstract No. 42-1-62.)

46. Isometries of closed 2-dimensional analytic Riemannian manifolds into themselves, by Dr. S. B. Myers (National Research Fellow). (Abstract No. 42-1-59.)

47. On the Cevian terrahedron, by Professor Nathan AltshillerCourt. (Abstract No. 42-1-23.)

48. Asymptotic lines through a planar point of a surface and lines of curvature through an umbilic, by Dr. T. L. Downs, Jr. (Abstract No. 42-1-31-t.)

49. On the differential line-geometry of space associated with the linear conformal transformations of the dual sphere (preliminary report), by Dr. Robin Robinson. (Abstract No. 42-1-58.)

50. Cross-points of lines on a cubic surface, by Professor H. S. White. (Abstract No. 42-1-71.)

51. A new form of the four-vertex theorem, by Professor W. C. Graustein. (Abstract No. 42-1-76.)

52. Applicability with preservation of both curvatures, by Professor W. C. Graustein. (Abstract No. 42-1-77.)

53. The Schönemann-Eisenstein irreducibility criteria in terms of prime ideals, by Dr. Saunders MacLane. (Abstract No. 41-11383.)

54. The maximal orders of generalized quaternion division algebras, by Dr. Ralph Hull. (Abstract No. 42-1-1-t.)

55. Sets of functions and their limit functions, by Professor H. J. Ettlinger and Mr. O. H. Hamilton. (Abstract No. 42-1-2-t.)

56. A note on the associative law in logical algebras, by Professor H. B. Curry. (Abstract No. 42-1-4-t.)

57. Differentiable functions defined in arbitrary subsets of euclidean space, by Professor Hassler Whitney. (Abstract No. 421-5-t.)

58. On the dynamics of commutator machines, by $\mathrm{Mr}$. W. H. Ingram. (Abstract No. 42-1-7-t.)

59. On a method for evaluating the moments of a Bernoulli distribution, by Mr. E. H. Larguier. (Abstract No. 42-1-8-t.)

60. Note on a singular integral. II, by Dr. E. P. Northrop. (Abstract No. 42-1-9-t.) 
61. A critique of the continuum, by Professor A. H. Copeland (Guggenheim Fellow). (Abstract No. 42-1-10-t.)

62. The minimum of a definite integral with respect to unilateral rariations, by Professor J. D. Mancill. (Abstract No. 42-1-17-t.)

63. On the summability of Fourier series, by Dr. W. C. Randels. (Abstract No. 42-1-19-t.)

64. On universal Waring theorems for cubic functions (preliminary report), by Mr. Alvin Sugar. (Abstract No. 42-1-20-t.)

65. New results for the number $g(n)$ in Waring's problem, by Mr. H. S. Zuckerman. (Abstract No. 42-1-21-t.)

66. A note on topological groups, by Mr. Garrett Birkhoff. (Abstract No. 42-1-15-t.)

67. Highly composite ideals, by Professor R. G. Archibald. (Abstract No. 42-1-28-t.)

68. The Jacobi series on an unrestricted lemniscate, by Dr. J. H. Curtiss. (Abstract No. 42-1-30-t.)

69. Collections filling a plane, by Professor J. H. Roberts. (Abstract No. 42-1-39-t.)

70. Sets which satisfy certain avoidability conditions, by Professor R. L. Wilder. (Abstract No. 42-1-42-t.)

71. Group velocity, by Dr. D. G. Bourgin. (Abstract No. 42-144-t.)

72. On some asymptotic formulas in the additive theory of numters, by Professor Leonard Carlitz. (Abstract No. 42-1-48-t.)

73. Special regions of regularity of functions of several complex variables, by Dr. W. T. Martin (National Research Fellow). (Abstract No. 42-1-50-t.)

74. Concerning essential continua of condensation, by Professor R. L. Moore. (Abstract No. 42-1-51-t.)

75. Fundamental systems of units in normal fields, by Professor M. J. Weiss. (Abstract No. 42-1-53-t.)

76. On elementary number theory, by Dr. Max Zorn. (Abstract No. 42-1-55-t.)

77. On subanalytic spaces. I, by Dr. Max Zorn. (Abstract No. 42-1-63-t.)

78. Almost periodic properties of bounded solutions of linear differential equations with almost periodic coefficients, by $\mathrm{Dr} . \mathrm{R}$. H. Cameron. (Abstract No. 42-1-57-t.)

79. On singular Fourier-Stieltjes transforms, by Mr. R. B. Kershner. (Abstract No. 42-1-60-t.)

M. H. Ingraham, Associate Secretary 